\title{
PEMBERLAKUAN SIFAT MELAWAN HUKUM MATERIIL BERFUNGSI NEGATIF DALAM TINDAK PIDANA KORUPSI
}

Oleh:

Septri Yustisiani

\begin{abstract}
Law No. 31 of 1999 in connection with Law No. 20 of 2001 regarding Corruption Eradication has included the unlawful element, in both procedural and substantive nature, when formulating the corruption act provision. In the legal doctrine, the substantive unlawful nature is categorized, based on its function, into two categories, namely positive and negative. The negative substantive unlawful nature is important to keep the spirit in eradicating corruption to not run amok, and to give protection to the actor, which is innocent based on substantive law. However, such criminal law policy, that accommodates substantive unlawful nature, has been declared as not legally binding by the Constitutional Court in its Decision No. 003/PUUIV/2006 as it is considered conflicting with the legal certainty, which is one of the principles in the rule of law. Therefore, this research will analyze the above decision and the continuity in applying the negative function of the substantive unlawful nature to the corruption crime, which could be seen from the court decisions; and relates it, with the purpose of law.
\end{abstract}

Keywords: The negative substantive unlawful nature, corruption, court decisions, The legal doctrine, Criminal law policy.

\section{PENDAHULUAN}

Indonesia dikategorikan sebagai salah satu negara dengan jumlah korupsi terbanyak di dunia. Semakin hari, jumlah kasus korupsi semakin meningkat, dan cara yang dilakukan pun semakin beragam. ${ }^{1}$ Korupsi adalah salah satu bentuk kejahatan luar biasa (extra ordinary crime) yang dilakukan oleh seseorang yang terhormat, berkuasa, memiliki kewenangan, yang melakukan suatu perbuatan tidak patut, dan menusuk perasaan hati masyarakat banyak karena telah menyalahgunakan kepercayaan yang

\footnotetext{
${ }^{1}$ Romli Atmasasmita, Analisis dan Evaluasi Hukum tentang Penyelidikan dan Penyidikan Tindak Pidana Korupsi, Jakarta: Badan Penelitian Pembinaan Nasional Departemen Hukum Dan HAM, 2007, hlm. 9.
}

diberikan. ${ }^{2}$ Sangat disadari bahwa tindak pidana korupsi ini telah menimbulkan dampak sistemik yang berkepanjangan dan kerusakan moral. Bila dilihat dari akibat yang ditimbulkannya, kejahatan ini merupakan salah satu perbuatan yang paling membahayakan kepentingan negara, sebab kejahatan korupsi ini menyebabkan kerugian keuangan yang sangat besar. ${ }^{3}$

Keuangan negara yang seharusnya dapat digunakan untuk pembangunan, tetapi malah digunakan secara tidak bertanggungjawab. Dana yang seharusnya diperuntukan sebagai

\footnotetext{
2 Marwan Mas, Pemberantasan Tindak Pidana Korupsi, Bogor: Ghalia Indonesia, 2014, hlm. 3.

${ }^{3}$ Gatot Supramono, Tindak Pidana Korupsi di Bidang Perkreditan, Bandung: Alumni, 1997, hlm. 66.
} 
subsidi pupuk kepada petani, biaya pendidikan dan kesehatan, hingga pembangunan untuk masyarakat luas, semuanya belum dapat tercapai secara maksimal karena korupsi telah melemahkan kemampuan keuangan Negara. Misalnya saja, dalam dunia usaha, investasi yang diperlukan untuk meningkatkan usaha menjadi sangat mahal karena setiap proses ekonominya harus melewati pintu korupsi. ${ }^{4}$ Semuanya ini tentu saja menghambat perkembangan kegiatan usaha, sehingga tindak pidana ini perlu penanganan yang dilakukan secara khusus, dan segera.

Korupsi mengakibat kerugian negara yang sangat besar. Hal ini dapat dilihat, salah satunya dari Corruption Perceptions Index (CPI) atau Indeks Persepsi Korupsi (IPK). Dari rentang skor IPK 0-100, nilai indeksi persepsi Indonesia stagnan pada tahun 20122013 berada pada angka 31 sebagaimana yang dimuat dalam Kompas tahun 2014. Kondisi ini menyebabkan Indonesia yang semula menempati urutan 118 menjadi naik ke urutan 114 dari 176 negara yang disurvei. Kenaikan urutan ini tidak disebabkan oleh kenaikan IPK yang disebabkan oleh kinerja atau prestasi pencegahan dan pemberantasan korupsi yang semakin membaik, tetapi dikarenakan IPK negara-negara lainnya yang semakin memburuk. Selain itu, IPK tersebut merupakan indeks komposit yang keberadaan skornya ditentukan oleh elemen tertentu. Misalnya saja, kenaikan IPK

\footnotetext{
${ }^{4}$ Arya Maheka, Mengenali \& Memberantas Korupsi, Komisi Pemberantasan Korupsi, Jakarta: Komisi Pemberantasan Korupsi, tidak bertahun, hlm. 6.

${ }^{5}$ Joko Ade Nursiyono, "Jika Uang Korupsi Menjadi Bekal Membangun Negeri", diakses dari http://www.kompasiana.com/jokoade/jika-uangkorupsi-menjadi-bekal-membangunnegeri_54f71b04a3331146228b4856, pada tanggal 27 Juli 2015 pukul 03.00wib.
}

Indonesia dikarenakan pemerintah telah mengurangi tindakan korupsi pada lembaga pemerintahan, tetapi bila dilihat dari aspek lain, pengawasan terhadap kelembagaan lainnya kurang tersentuh. ${ }^{5}$

Salah satu upaya pemberantasan korupsi yang dilakukan dari sudut hukum adalah dengan memperbaiki perundang-undangan dan menjadikannya senjata yang ampuh, sehingga dibuatlah peraturan yang khusus mengenai perbuatan korupsi dalam UndangUndang tersendiri yang terpisah dari KUHP atau di luar kodifikasi. ${ }^{6}$ Ketentuan tentang Pemberantasan Tindak Pidana Korupsi ini diatur dalam Undang-Undang No. 3 Tahun 1971 yang kemudian telah diubah menjadi Undang-Undang No.31 Tahun 1999. Pada peraturan yang baru, terdapat perubahan terhadap pengertian korupsi, yaitu dengan memasukkan unsur melawan hukum ke dalam perumusan delik dengan tujuan awalnya untuk dapat menjangkau berbagai modus operandi korupsi, dan meminimalisasi celah hukum yang dijadikan para pelaku sebagai alasan untuk melepaskan diri dari jerat hukum. $^{7}$

Seperti tindak pidana pada umumnya, dalam tindak pidana korupsi pun unsur setiap unsur harus dibuktikan, termasuk unsur melawan hukum yang pada bagian penjelasan pasal mengenai pengertian korupsi disebutkan bahwa yang dimaksud dengan melawan hukum di sini adalah melawan hukum formil dan materiil. Dalam

\footnotetext{
${ }^{6}$ Indriyanto Seno Adji, Tindak Pidana Ekonomi, Bisnis, dan korupsi Perbankan, Modul Kuliah "Kejahatan Bisnis", Bandung: Universitas Padjajaran Program Pascasarjana, 2004, hlm. 30.

${ }^{7}$ Chaerudin, dkk, Strategi Pencegahan dan Penegakan Hukum Tindak Pidana Korupsi, Bandung: Refika Aditama, 2008, hlm. 5.
} 
doktrin hukum, ajaran sifat melawan hukum ini mempunyai dua fungsi, yaitu fungsi positif dan fungsi negatif. Sifat melawan hukum dari keduanya berdasarkan pada hukum tidak tertulis, seperti asas-asas umum di masyarakat. Akan tetapi, kedua fungsi ini sangat berbeda peranannya. Sifat melawan hukum materiil positif berdasarkan hukum tidak tertulis, yaitu penilaian masyarakat terhadap suatu perbuatan yang dianggap tercela, meskipun tidak memenuhi rumusan delik, maka secara positif perbuatan pelaku tersebut dianggap sebagai perbuatan melawan hukum. Sifat melawan hukum materiil negatif berdasarkan hukum tidak tertulis, yaitu pandangan masyarakat bahwa suatu perbuatan tidak tercela atau tidak melawan hukum secara materiil, meskipun telah memenuhi rumusan delik, maka pelaku dilepaskan dari segala tuntutan hukum. ${ }^{8}$

Berbicara tentang sifat melawan hukum, unsur ini pada dasarnya sulit untuk dibuktikan karena adanya perbedaan pandangan antara Undang-Undang dengan masyarakat mengenai perbuatan yang dipandang koruptif. Untuk itu, pembuat peraturan telah mengakui keberadaan sifat melawan hukum materiil berfungsi negatif yang memberi pengakuan terhadap pandangan masyarakat mengenai tercela atau tidaknya suatu perbuatan dalam UndangUndang Tindak Pidana Korupsi. Akan tetapi, karena sifat kekhususannya yang dianggap sangat merugikan Negara dan mencederai hati rakyat, maka keberadaan ajaran sifat melawan hukum materiil berfungsi negatif dalam tindak pidana khusus ini tetap menjadi pertanyaan dalam pemberlakuannya.

${ }^{8}$ Erdianto Effendi, Hukum Pidana Indonesia, Suatu Pengantar, Bandung: Refika Aditama, 2011, hlm. 118.
Tafsiran terhadap unsur melawan hukum materiil negatif dapat terlihat dari putusan pengadilan dalam menyelesaikan kasus konkrit, seperti Putusan Mahkamah Agung No. 42/K/Kr/1965 yang menerapkan ajaran ini. Perkara ini terjadi karena terdakwa, Machrus Effendi yang menjabat sebagai patih pada Kantor Bupati Sambas, telah mengeluarkan D.O gula insentif padi yang menyimpang dari tujuannya. Gula insentif tersebut sesungguhnya hanya boleh dikeluarkan dalam rangka pembelian padi untuk Pemerintah dari para petani dan menjual gula kepada mereka yang menjual padi kepada Pemerintah. Akan tetapi, terdakwa telah mengeluarkan D.O gula insentif padi tersebut untuk keperluan lainnya, seperti untuk ongkos pengangkutan giling, buruh, dan jasa-jasa lain. Adapun kelebihan harga dari penjualan, terdakwa kemudian gunakan untuk pembangunanpembangunan daerah diantaranya untuk menyelesaikan rumah milik Pemerintah Daerah.

Dengan berbagai pertimbangan terhadap kasus di atas, Pengadilan Tinggi berpendapat bahwa tindakan terdakwa sesungguhnya merupakan tindakan yang menyimpang dari tujuan awal yang telah ditentukan. Akan tetapi, perbuatan-perbuatan terdakwa tersebut jika ditinjau dari sudut kemasyarakatan, perbuatan terdakwa tersebut justru merupakan wujud pelayanan yang menguntungkan masyarakat, dan dapat disebut juga melayani kepentingan umum. Adakalanya kebijaksanaan seperti ini kadang-kadang terpaksa dihadapi dan diambil oleh aparatur pemerintah daerah 
demi kelancaran pembangunan atau demi kepentingan masyarakat daerah. Oleh sebab itu, dalam putusannya Mahkamah Agung juga menyatakan pendapat yang serupa dengan Pengadilan Tinggi, dimana suatu perbuatan pada umumnya dapat hilang sifat melawan hukumnya bukan hanya berdasarkan suatu ketentuan dalam perundang-undangan, melainkan juga berdasarkan asas-asas keadilan atau asas-asas hukum yang tidak tertulis dan bersifat umum. Dalam perkara ini disebutkan beberapa faktor yang menjadi kriteria atau tolak ukur yang digunakan untuk menghapuskan sifat melawan hukum, yaitu: ${ }^{9}$

- negara tidak dirugikan,

- kepentingan umum dilayani, dan

- terdakwa sendiri tidak mendapat untung.

Jelaslah bahwa dalam perkembangannya, sifat melawan hukum materiil dalam fungsi negatif pun mulai diperhatikan, dan pada kasus tertentu bisa jadi sifat melawan hukum materiil dalam fungsi negatif ini dapat menjawab kebutuhan dari perluasan sifat melawan hukum pada tindak pidana korupsi di Indonesia.

Kaidah hukum mengenai tolak ukur dalam Putusan MA 1965 tersebut menjadi yurisprudensi dan arahan bagi hakim lainnya untuk juga menerapkan fungsi negatif dari sifat melawan hukum dalam menyelesaikan kasus tindak pidana korupsi. Hal ini tetap sejalan dengan rumusan Pasal korupsi pada Undang-Undang No. 31 Tahun 1999 yang berlaku setelahnya. Akan tetapi, Mahkamah
Konstitusi mengeluarkan Putusan No. 003/PUU-VI/2006 yang memutuskan bahwa, “.... pada Pasal 2 ayat (1) dan Pasal 3 Undang-undang Nomor 31 Tahun 1999 tentang Pemberantasan Tindak Pidana Korupsi, sebagaimana diubah dengan Undang-undang Nomor 20 Tahun 2001, beserta penjelasan-penjelasannya dan kalimat, “. ... maupun dalam arti materiil, yakni meskipun perbuatan tersebut tidak diatur dalam peraturan perundangundangan namun apabila perbuatan tersebut dianggap tercela karena tidak sesuai dengan rasa keadilan atau normanorma kehidupan dalam masyarakat, maka perbuatan tersebut dapat dipidana" dinyatakan tidak mengikat secara hukum karena bertentangan dengan Pasal 28D ayat (1) Undang-Undang Dasar Negara Republik Indonesia Tahun 1945."

Dengan menyatakan bahwa sifat melawan hukum materiil tidak mengikat secara hukum, maka telah terjadi kekosongan hukum untuk menerapkan sifat melawan hukum materiil, termasuk dalam fungsinya yang negatif pada kasus tindak pidana korupsi.

Perihal di atas mengakibatkan hakim yang memegang peranan dalam mengadili perkara, perlu melakukan penafsiran atau bahkan penemuan hukum untuk mempertimbangkan pemberlakuan sifat melawan hukum materiil negatif dan keterkaitannya dengan tujuan hukum. Untuk itu, maka perlu ditelaah lebih jauh mengenai hal berikut ini:

\footnotetext{
${ }^{9}$ Komariah Emong Sapardjaja, Ajaran Sifat MelawanHukum Material Dalam Hukum Pidana Indonesia, Jakarta: Mahkamah Agung RI, 2008, hlm. 133.
} 
Apakah kriteria atau tolak ukur dari hukum tidak tertulis yang merupakan dasar dari sifat melawan hukum materiil negatif yang digunakan dalam Putusan Mahkamah Agung No. 42/K/Kr/1965 masih relevan untuk diberlakukan Pasca Putusan Mahkamah Konstitusi No. 003/PUUVI/2006?

\section{PEMBAHASAN}

\section{Ajaran Sifat Melawan Hukum Materiil Negatif dalam Hukum Pidana}

Pengertian hukum pidana telah coba dirumuskan oleh beberapa ahli hukum, salah satunya adalah R. Soesilo yang memberi pandangan bahwa pidana atau hukuman tersebut merupakan suatu perasaan yang tidak enak (sengsara) yang dijatuhkan oleh hakim sebagai vonis kepada orang yang telah melanggar undang-undang hukum pidana. Penjatuhan pidana adalah suatu nestapa bagi pelanggar, sehingga hal ini hanya digunakan sebagai obat terakhir (ultimum remedium), yang akan digunakan bilamana usaha-usaha lain seperti pencegahan sudah tidak berjalan. ${ }^{10}$

Hukum pidana juga dirumuskan oleh WLG. Lemaire yang mengemukakan bahwa perbedaan mendasar antara hukum pidana dengan bidang hukum lainnya terletak pada norma-norma dalam hukum pidana yang berisi keharusan-keharusan dan laranganlarangan yang oleh pembentuk UndangUndang telah dikaitkan dengan suatu sanksi berupa hukuman yakni suatu penderitaan yang bersifat khusus. ${ }^{11}$ Pengertian dari kedua ahli di atas telah memberikan gambaran

\footnotetext{
${ }^{10}$ Erdianto Effendi, op.cit, hlm. 2.

${ }^{11}$ Ibid, hlm. 7.

${ }^{12}$ Evi Hartanti, Tindak Pidana korupsi, Jakarta: Sinar Grafika, 2014, hlm. 6.
}

bahwa dalam hukum pidana terdapat ketentuan-ketentuan yang telah dibuat oleh negara melalui peraturan yang apabila dilanggar maka pelakunya akan dijerat dengan hukuman berupa penderitaan yang bersifat khusus yang digunakan sebagai ultimum remedium.

Dalam hukum pidana, hal utama yang diatur adalah mengenai tindak pidana atau straafbaarfeit. Tindak pidana sering disebut Utrecht dengan istilah peristiwa pidana atau peristiwa hukum karena membawa akibat sebagaimana yang telah diatur oleh hukum. ${ }^{12}$ Peristiwa pidana ini terjadi bilamana suatu perbuatan bertentangan atau menghambat terlaksananya tata pergaulan masyarakat yang dianggap baik dan adil, dan perbuatan ini merugikan masyarakat. Akan tetapi, memang tak semua perbuatan yang merugikan masyarakat dan yang melawan hukum, dapat disebut sebagai perbuatan pidana, dan dapat diberi sanksi pidana. Oleh karena itu, pemerintah berkewajiban untuk memberikan kebijakan yang menyesuaikan apa-apa yang ditentukan sebagai perbuatan pidana.

Penentuan tersebut sangat dipengaruhi oleh perasaan hukum yang hidup dalam masyarakat, dan pandangan-pandangan apakah ancaman dan penjatuhan pidana terhadap perbuatan tersebut merupakan jalan utama untuk mencegah tidak terjadinya pelanggaran. ${ }^{13}$ Kebijakan pemerintah yang dinyatakan dalam aturan hukum pidana mengenai suatu perbuatan yang dilarang dikenal dengan istilah delik, dan barangsiapa memenuhi rumusannya, melawan hukum,

13 Roeslan Saleh, Perbuatan Pidana dan Pertanggungjawaban Pidana, Dua Pengertian Dasar Dalam Hukum Pidana, Jakarta: Aksara Baru, 1983, hlm. 13. 
dan bersalah karena telah melakukan, maka pelaku dinyatakan telah melakukan tindak atau perbuatan pidana. ${ }^{14}$

Untuk terjadinya suatu tindak pidana, Enschede mengungkapkan bahwa,

"een strafbaar feit is een menselijke gedraging, die valt binnen de grenzen van een delictsomschrijving, wederrechtelijk is en aan schuld te wijten" (tindak pidana adalah suatu perbuatan manusia, yang termasuk dalam perumusan delik, melawan-hukum dan kesalahan yang dapat dicelakan padanya). ${ }^{15}$

Sebagaimana yang tercantum dalam pendapat di atas, bahwa syarat utama terjadinya perbuatan pidana adalah harus adanya perbuatan yang dilakukan orang yang melanggar ketentuan dalam perundangundangan pidana, dan syarat kedua yaitu perbuatan yang dimaksud harus juga bersifat melawan hukum (seperti membunuh musuh di medan perang), atau tidak dapat dicela (bilamana pelaku berada dalam kesesatan yang dapat dimaafkan). ${ }^{16}$ Seperti yang dijelaskan secara singkat dengan konsep di bawah ini: ${ }^{17}$

1. Perbuatan pidana, yaitu perbuatan yang harus diatur dalam undangundang pidana sebagai tindakan yang dilarang, dan diancam dengan sanksi tertentu. ${ }^{18}$ Oleh karena itu, seturut dengan prinsip dalam asas legalitas, bilamana suatu perbuatan yang dirasakan melawan hukum tetapi

\footnotetext{
${ }^{14}$ Indriyanto Seno Adji, op.cit, hlm. 37.

${ }^{15}$ Komariah Emong Sapardjaja, op.cit, hlm. $14-15$.

${ }^{16}$ Schaffmeister, dkk, Terjemahan JE. Sahetapy dan Agustinus Pohan, Hukum Pidana, Bandung: Citra Aditya Bakti, 2011, hlm. 26.

${ }^{17}$ R. Achmad S. Soemadi Praja, Pengertian Serta Sifatnya Melawan Hukum bagi Terjadinya Tindak
}

tidak ada ketentuan pidana yang mengaturnya, maka pelaku tidak dapat dijerat dengan sanksi pidana.

2. Pertanggungjawaban pidana, yaitu perbuatan tersebut harus dapat dipertanggungjawabkan dalam arti dapat dicela (unsur kesalahan), dan bersifat melawan hukum. Dalam doktrin hukum bentuk pertanggungjawaban pidana ini dapat dijelaskan secara ringkas, sebagai berikut :

a. dasar-dasar peniadaan kesalahan (alasan pemaaf), yaitu alasanalasan yang berkaitan dengan kesalahan pelaku, dimana pada dasarnya tiada pidana tanpa kesalahan. Alasan ini dapat digunakan sebagai dasar penghapus pidana, bilamana perbuatan seseorang yang telah dilakukan mencocoki rumusan delik, tetapi terhadap pelaku sesungguhnya tidak patut disalahkan atau tidak sepantasnya orang itu dicela, maka hal-hal yang menjadi dasar pelaku tidak sepantasnya dicela tersebut disebut sebagai hal-hal yang dapat memaafkan, atau alasan pemaaf. 19 Karena alasan penghapus pidana ini menyangkut dari dalam diri pribadi pelaku, maka dasar ini bila dilihat dari unsur delik,

Pidana (Dihubungkan dengan Beberapa Putusan Mahkamah Agung), Bandung: Armico, 1983, hlm. 18. ${ }^{18}$ Schaffmeister, N. Keijzer, E. PH. Sutorius, supra catatan no. 17 , hlm. 1 .

${ }^{19}$ H. M. Hamdan, Alasan Penghapusan Pidana, Teori dan Studi Kasus, Bandung: Refika Aditama, 2012, hlm. 30. 
disebut juga sebagai unsur subjektif, dimana alasan pemaaf tersebut melekat dan berlaku hanya untuk diri pelaku sendiri.

b. dasar-dasar peniadaan sifat melawan hukum (alasan pembenar), yaitu alasan-alasan yang menghapus sifat melawan hukumnya perbuatan. Alasan ini dapat digunakan sebagai dasar penghapus pidana, bilamana perbuatan seseorang yang telah dilakukan mencocoki rumusan delik, tetapi terdapat hal-hal yang menyebabkan tidak adanya sifat melawan hukum dari perbuatan tersebut, maka hal-hal itulah yang dikatakan sebagai alasan-alasan pembenar yang menghapuskan atau menghilangkan sifat melawan hukum dari suatu perbuatan atau tindakan. Dengan kata lain, perbuatan ini menjadi perbuatan yang dapat dibenarkan atau perbuatan yang tidak tercela, sehingga berlaku sebagai alasan pembenar untuk semua orang yang melakukan perbuatan tersebut dalam kejadian atau kondisi tertentu. Karena alasan penghapus pidana ini menyangkut dari luar diri pribadi pelaku, maka dasar ini bila dilihat dari unsur delik, disebut juga sebagai unsur objektif, dimana alasan pembenar tersebut menyangkut tentang perbuatan yang menjadi dibenarkan. ${ }^{20}$
Seperti yang telah dipaparkan pada bagian pendahuluan, bahwa menurutilmu hukum, dasar alasan pembenar tersebut dapat bersumber dari hukum tertulis seperti yang dianut dalam ajaran sifat melawan hukum formal, dan dapat bersumber dari hukum tidak tertulis seperti yang diterapkan dalam ajaran sifat melawan hukum materiil berfungsi negatif. Salah satu pendapat mengenai perbuatan melawan hukum materiil ini diungkapkan oleh Moeljatno yang juga mengatakan ketidaksependapatnya dengan pandangan bahwa hukum adalah undang-undang. Lebih lanjut beliau mengatakan bahwa,

"Pikiran bahwa Hukum adalah Undang Undang belum pernah kita alami. Bahkan sebaiknya, hampir semua Hukum Indonesia Asli ada hukum yang tidak tertulis. Kiranya perlu dipertegas disini bahwa dimana peraturan-peraturan Hukum Pidana kita sebagian besar telah dimuat dalam KUHP dan lain-lain perundang-undangan, maka pandang-an tentang hukum dan sifat melawan hukum materil di atas, hanya mempunyai arti dalam memperkecualikan perbuatan yang meskipun masuk dalam perumusan Undang Undang itu, toh tidak merupakan perbuatan pidana. Biasanya itu dinamakan fungsi yang negatif dari sifat melawan hukum yang materil". ${ }^{21}$

Sejalan dengan pendapat tersebut, Wirjono Prodjodikoro juga berpendapat bahwa sifat melawan hukum materiil berfungsi negatif tetap diperlukan sebagai dasar alasan pembenar yang menghilangkan sifat melawan hukum, sehingga perbuatan pelaku yang pada dasarnya merupakan tindak pidana (Rechtsvaardigingsgrond) menjadi diperbolehkan atau dihalalkan karena

\footnotetext{
${ }^{21}$ Indriyanto Seno Adji, op.cit, hlm. 49-50.
}

${ }^{20}$ Ibid, hlm. 31. 
hilangnya sifat melawan hukum dari perbuatan tersebut. ${ }^{22}$ Pendapat-pendapat tersebut dengan tegas menyatakan bahwa perbuatan melawan hukum secara materiil harus selalu diartikan dalam fungsinya yang negatif, dimana suatu perbuatan sebenarnya telah memenuhi rumusan delik atau dipandang telah terbukti melawan hukum secara formil, akan tetapi perbuatan itu ternyata dipandang oleh masyarakat sebagai perbuatan yang tidak tercela atau tidak melawan hukum secara materiil, maka pelaku tersebut dilepaskan dari segala tuntutan hukum, dimana perkecualiannya adalah berasal dari ilmu Hukum (di luar Undang-Undang).

\section{Pemberlakuan Sifat Melawan Hukum Materiil Negatif dalam Tindak Pidana Korupsi}

Bila dilihat secara historis, unsur 'melawan hukum' dalam Undang-Undang No. 31 Tahun 1999 berasal dari UndangUndang No. 3 tahun 1971 tentang Tindak Pidana Korupsi yang dirumuskan untuk mengatasi kelemahan Undang-Undang No. 24/Prp/1960 yang memasukan syarat adanya kejahatan atau pelanggaran yang dalam praktek sulit untuk dibuktikan. ${ }^{23}$ Oleh karena itu, Undang-Undang No. 3 Tahun 1971 menggantinya menjadi unsur melawan hukum yang meskipun tidak dimunculkan dalam Pasal 1 ayat (1) sub b, tetapi istilah perbuatan menyalahgunakan kewenangan dalam rumusan tersebut secara terselubung juga mengandung sifat melawan hukum, dimana pelaku pada dasarnya tidak memiliki

\footnotetext{
${ }^{22}$ Ibid, hlm. 49.

${ }^{23}$ Barda Nawawi Arief, Pembaharuan Hukum Pidana Dalam Perspektif Kajian Perbandingan, Bandung: Citra Aditya Bakti, 2011, hlm. 35.
}

hak (melawan hukum) untuk menyalahgunakan kewenangannya. 24 Ketentuan ini semakin disempurnakan melalui Undang-Undang No. 31 Tahun 1999, sebagai upaya pemerintah dan pembuat Undang-Undang untuk mendorong institusi yang berwenang dalam melakukan pemberantasan, terkhususnya agar dapat menjangkau berbagai modus operandi korupsi, dan meminimalisasi celah hukum yang dijadikan para pelaku sebagai alasan untuk melepaskan diri dari jerat hukum. ${ }^{25}$

Mengingat tentang bahaya korupsi seperti yang telah dijelaskan pada bagian awal, maka pemerintah melakukan berbagai upaya untuk memberantas tindak pidana ini. Semangat pemberantasan dan anti korupsi tersebut tertuang di dalam Pasal 4 Tap MPR No. IX/MPR/1998 tentang Penyelenggaran Negara yang Bersih dan Bebas Korupsi, Kolusi, dan Nepotisme, seperti berikut:

"Upaya pemberantasan korupsi, kolusi, dan nepotisme harus dilakukan secara tegas terhadap siapapun juga, baik pejabat negara, mantan pejabat negara, keluarga, dan kroninya maupun pihak swasta/ konglomerat termasuk mantan Presiden Soeharto dengan tetap memperhatikan prinsip praduga tak bersalah dan hak-hak asasi manusia."

Ketentuan ini dibuat karena menyadari bahwa penindakan terhadap perilaku tindak pidana korupsi tidaklah mudah, karena para pelaku mempunyai kedudukan atau jabatan yang dapat menutupi perbuatannya sehingga menjadi sulit untuk dibuktikan secara hukum.

\footnotetext{
${ }^{24}$ H. Adami Chazawi, Hukum Pembuktian Tindak Pidana Korupsi UU No. 31 Tahun 1999 diubah dengan UU No. 20 Tahun 2001, Bandung: Alumni, 2008, hlm. 306.

${ }^{25}$ Chaerudin, et.all, loc.cit.
} 
Oleh sebab itu, dengan semangat pemberantasan korupsi, dilakukanlah upaya yang gencar, yang pada saat itu dilakukan terhadap dugaan korupsi yang ditujukan kepada mantan Presiden Soeharto yang dipandang telah melakukan penyelewengan kekuasaan yang menguntungkan diri sendiri, keluarga, kroninya, atau orang lain yang berakibat pada kerugian keuangan negara. ${ }^{26}$

Perlu diperhatikan, bahwa dalam upaya pemberantasan sekalipun penegakan hukum tidak boleh dilakukan secara membabi buta, dengan menyamaratakan setiap perbuatan, tanpa mempertimbangkan nilai hukum yang ada. Hal ini tidak dapat dibenarkan, sehingga peraturan selanjutnya mengakomodir nilai hukum tersebut, dan memberikan pengakuan terhadap pemberlakuannya.

Peraturan yang dimaksud adalah Undang-Undang No. 31 Tahun 1999 tentang Pemberantasan Tindak Pidana Korupsi, yang mencantumkan unsur melawan hukum di dalam ketentuannya, sebagaimana yang terdapat dalam Pasal 2 ayat (1) yang berbunyi:

"Setiap orang yang secara melawan hukum melakukan perbuatan memperkaya diri sendiri atau orang lain uang suatu korporasi yang dapat merugikan keuangan negara atau perekonomian negara, dipidana dengan pidana penjara seumur hidup atau pidana penjara paling secara singkat 4 (empat) tahun dan paling lama 20 (dua puluh) tahun dan denda paling sedikit Rp. 200.000.000,00 (dua ratus juta rupiah) dan paling banyak Rp.1.000.000.000,00 (satu milyar rupiah)."

Pengertian ini ditegaskan dalam bagian penjelasan pasalnya,
"Yang dimaksud dengan "secara melawan hukum" dalam Pasal ini mencakup perbuatan melawan hukum dalam arti formil maupun dalam arti materiil, yakni meskipun perbuatan tersebut tidak diatur dalam peraturan perundang-undangan. Namun apabila perbuatan tersebut dianggap terela karena tidak sesuai dengan rasa keadilan atau norma-norma kehidupan sosial masyarakat. Maka perbuatan tersebut dapat dipidana."

Berdasarkan isi dan bagian penjelasan di atas, pembuat Undang-Undang menekankan bahwa peraturan ini menganut ajaran sifat melawan hukum formil dan sifat melawan hukum materiil. Artinya, suatu perbuatan disebut melawan hukum apabila bertentangan dengan peraturan perundangundangan yang berlaku, atau dipandang tercela karena bertentangan dengan rasa keadilan atau norma-norma kehidupan sosial dalam masyarakat. Akan tetapi, sesuai dengan ajaran sifat melawan hukum materiil dalam hukum pidana, maka fungsi positif yang dimaksud di sini tidak dapat diterapkan, dan hanya fungsi negatiflah yang dapat diberlakukan dalam perkara tindak pidana korupsi, yaitu sebagai alasan pembenar yang menghapus sifat melawan hukum dari suatu perbuatan.

Putusan Mahkamah Konstitusi mengenai Sifat Melawan Hukum Materiil dalam Tindak Pidana Korupsi

Upaya penafsiran terhadap unsur sifat melawan hukum materiil dalam tindak pidana korupsi juga dilakukan oleh Mahkamah konstitusi. Dawud Djatmiko yang tersangkut perkara dugaan korupsi

\footnotetext{
${ }^{26}$ Marwan, op.cit, hlm. 17.
} 
dalam Jakarta Outer Ring Road mengajukan pengujian kepada Mahkamah Konsitusi, salah satunya terhadap bagian penjelasan dari ketentuan Pasal 2 Undang-Undang Nomor 31 tahun 1999 tentang Tindak Pidana Korupsi yang diubah dengan Undang-Undang Nomor 20 Tahun 2001 yang berkaitan dengan penerapan unsur perbuatan melawan hukum materiil.

Hakim Mahkamah Konstitusi menilai bahwa memang terdapat persoalan konstitusional dalam bagian penjelasan kalimat pertama pada Pasal 2 ini. Keberadaan sifat melawan hukum materiil berusaha untuk dijelaskan atau ditentukan lain oleh Mahkamah Konstitusi yang dalam Putusan No. 003/PUU-VI/2006 seperti yang tercermin dalam putusan akhirnya, sebagai berikut: ${ }^{27}$

"Penjelasan yang demikian telah menyebabkan kriteria perbuatan melawan hukum (Pasal 1365 KUHPerdata) yang dikenal dalam hukum perdata yang dikembangkan sebagai jurisprudensi mengenai perbuatan melawan hukum (onrechtmatigedaad), seolah-olah telah diterima menjadi satu ukuran melawan hukum dalam hukum pidana (wederrechtelijkheid). Oleh karena itu, apa yang patut dan yang memenuhi syarat moralitas dan rasa keadilan yang diakui dalam masyarakat, yang berbeda-beda dari satu daerah ke daerah lain, akan mengakibatkan bahwa apa yang di satu daerah merupakan perbuatan yang melawan hukum, di daerah lain boleh jadi bukan merupakan perbuatan yang melawan hukum;"

\footnotetext{
27 Putusan Mahkamah Konstitusi No. 003/PUUVI/2006, diakses dari http://hukum.unsrat.ac.id/etc/putusan_mk_003_2006. pdf, diakses pada tanggal 27 Juni 2015 pukul 07.00 wib.
}

Pertimbangan Mahkamah Konstitusi ini tidak tepat sebab Pasal 1365 KUHPerdata menyebutkan bahwa, "Tiap perbuatan melawan hukum yang menimbulkan kerugian pada orang lain, mewajibkan orang yang bersalah menimbulkan kerugian itu, mengganti kerugian tersebut." Terhadap rumusan ini, harus dipenuhi empat unsur : ${ }^{28}$

1. perbuatan itu harus melawan hukum;

2. perbuatan itu harus menimbulkan kerugian;

3. perbuatan itu harus dilakukan dengan kesalahan;

4. antara perbuatan dan kerugian yang timbul harus ada hubungan kausal.

Keempat unsur tersebut harus terpenuhi untuk dapat dikatakan perbuatan melawan hukum (onrechtmatig). Pengertian onrechmatigedaad dalam hukum perdata, tidak dapat dipersamakan dengan wederrechteljikheid dalam hukum pidana. Meskipun keduanya diterjemahkan dengan istilah perbuatan melawan hukum, tetapi artinya berbeda. Onrechmatigedaad atau perbuatan melawan hukum dalam hukum perdata, terjadi apabila keempat unsur dalam rumusan Pasal 1365 KUHPerdata terpenuhi. Sedangkan wederrechteljikheid atau perbuatan melawan hukum dalam hukum pidana justru merupakan salah satu unsur agar suatu perbuatan dapat disebut sebagai tindak pidana (strafbaarfeit). Dengan kata lain, onrechmatigedaad pengertiannya sama dengan strafbaarfeit dalam hukum pidana. ${ }^{29}$

\footnotetext{
${ }^{28}$ Abdulkadir Muhammad, Hukum Perdata Indonesia, Bandung: Citra Aditya Bakti, 2000, hlm. 252.

${ }^{29}$ Satochid Kartanegara dan Pendapat2 Para Ahli Hukum Terkemuka, Telah dikupas ke dalam Bahasa Indonesia dari Bahasa Belanda, Hukum Pidana
} 
Perlu diingat bahwa dalam hukum pidana, untuk disebut terjadinya tindak pidana atau strafbaarfeit, yang pertama-tama tetap harus dipenuhi adalah rumusan delik atau perbuatan yang melanggar perbuatan perundang-undangan pidana, dan yang kedua barulah perbuatan yang dimaksud juga harus bersifat melawan hukum (wederrechteljikheid). ${ }^{30}$ Oleh sebab itu, menurut R. B. Budi Prastowo, putusan Mahkamah Konstitusi tersebut hanya merupakan pepesan kosong karena dalam hukum pidana, orang hanya dapat dipidana apabila memenuhi rumusan delik, yang salah satu unsur di dalamnya ialah unsur melawan hukum.

Menjadi jelas, bahwa sifat melawan hukum materiil positif memang tidak dapat diberlakukan dalam hukum pidana. Akan tetapi, sifat melawan hukum materiil lainnya, yaitu dalam fungsi negatif, seharusnya tetap dinyatakan berlaku. Hal ini berbeda dengan bagian akhir dari isi Putusan Mahkamah Konstitusi yang menyebutkan bahwa,

“... pada Pasal 2 ayat (1) dan Pasal 3 Undang-undang Nomor 31 Tahun 1999 tentang Pemberantasan Tindak Pidana Korupsi, sebagaimana diubah dengan Undang-undang Nomor 20 Tahun 2001, beserta penjelasan-penjelasannya dan kalimat, “... maupun dalam arti materiil, yakni meskipun perbuatan tersebut tidak diatur dalam peraturan perundangundangan namun apabila perbuatan tersebut dianggap tercela karena tidak sesuai dengan rasa keadilan atau normanorma kehidupan dalam masyarakat, maka perbuatan tersebut dapat dipidana" dinyatakan tidak mengikat secara hukum karena bertentangan dengan Pasal 28D

kumpulan kuliah (Balai Lektur Mahasiswa, tanpa penerbit, tanpa tahun, hlm. 412-414.

${ }^{30} \mathrm{R}$. Achmad, loc.cit. ayat (1) Undang-Undang Dasar Negara Republik Indonesia Tahun 1945."

Putusan tersebut hanya berpusatkan pada kepastian hukum semata, dan mengesampingkan tujuan hukum lainnya, dengan menyempitkan sumber hukum yang ada tidaklah dapat dibenarkan. Bagian penjelasan Undang-Undang Dasar 1945 menentukan bahwa bukan hanya hukum tertulis atau hukum yang dibuat penguasa semata yang menjadi sumber hukum di Indonesia, tetapi juga hukum tidak tertulis yang hidup dan berkembang di masyarakat.

Hukum tidak tertulis tetap merupakan hukum yang terhadapnya tetap dimungkinkan adanya perbuatan yang melanggar hukum yang bertentangan dengan tata tertib dan kepatutan yang selayaknya ada dalam pergaulan masyarakat, dan adanya alasan tertentu yang dapat digunakan sebagai dasar yang menghapus sifat melawan hukum dari suatu ketentuan, meskipun ketentuan tersebut diatur dalam hukum tertulis. Sehubungan dengan situasi dan kondisi Indonesia tersebut, ajaran sifat melawan hukum materiil negatif merupakan pilihan yang paling tepat untuk tetap diberlakukan dalam setiap delik, sekalipun tidak dicantumkan dalam rumusan. ${ }^{31}$

\section{Putusan Mahkamah Agung mengenai Sifat Melawan Hukum Materiil dalam Tindak Pidana Korupsi Setelah Putusan Mahkamah Konstitusi}

Pasca Putusan Mahkamah Konstitusi tersebut, Mahkamah Agung RI dalam praktiknya tetap menganut ajaran perbuatan melawan mukum materiil (materiele

${ }^{31}$ E.Y.Kanter, S.R. Sianturi, Asas-Asas Hukum Pidana di Indonesia dan Penerapannya, Jakarta: Storia Grafika, 2012, hlm. 160. 
wederrechtelijkheid) yang setidaknya tampak dari putusan yang telah berkekuatan hukum tetap (inkracht van gewijsde), yang disebutkan oleh Ninil Eva Yustina dalam penelitiannya mengenai Perbuatan Melawan Hukum Materiil (Materiil Wederrechtelijkeheid) dalam Tindak Pidana. Korupsi pada Praktik Peradilan Indonesia Pasca Putusan Mahkamah Konstitusi, diantaranya ialah Putusan Mahkamah Agung RI Nomor 2064K/Pid/2006 tanggal 8 Januari 2007 atas nama Terdakwa H. Fahrani Suhaimi, Putusan Mahkamah Agung RI Nomor 996 K/Pid/2006 tanggal 16 Agustus 2006 atas nama Terdakwa Hamdani Amin, Putusan Mahkamah Agung RI Nomor 1974K/Pid/2006 tanggal 13 Oktober 2006 atas nama Terdakwa Rusadi Kantaprawira, dan Putusan Pengadilan Negeri Kepanjen Nomor 91/Pid.B/2008/PN. Kpj. tanggal 29 April 2008 atas nama terdakwa Abdul Mukti, juga Putusan Pengadilan Negeri Kepanjen Nomor 1079/Pid.B/2007/PN.Kpj. tanggal 23 April 2008 atas nama terdakwa Prayitno. 32 Hal ini memperlihatkan, meskipun Putusan Mahkamah Konstitusi secara legislasi menyebabkan pengertian dari perbuatan melawan hukum materiil dalam tindak pidana korupsi menjadi tidak ada pengaturannya. Akan tetapi, perbuatan melawan hukum materiil eksistensinya tetap ada, dan diakui dalam praktik peradilan pidana.

Salah satu putusan Mahkamah Agung setelah adanya putusan Mahkamah Konstitusi mengenai sifat melawan hukum materiil yang digunakan untuk mewakili

\footnotetext{
${ }^{32}$ Ninil Eva Yustina, "Perbuatan Melawan Hukum Materiil (Materiel Wederrechtelijkeheid) Dalam Tindak Pidana Korupsi Pada Praktik Peradilan Indonesia Pasca Putusan Mahkamah Kontitusi”,
}

contoh perkara lainnya adalah kasus pengadaan tender tinta pemilu. Dimana, terdakwa Rusadi Kantaprawira dan rekannya Achmad Rojaditelah ditunjuk masingmasing selaku Sekretaris dan Ketua Panitia Pengadaan Tinta Sidik Jari yang digunakan dalam Pemilu. Pengadaan tinta sidik jari tersebut, menggunakan dana yang bersumber dari APBN 2004. Keduanya mengadakan rapat pengadaan tinta sidik jari terhadap 32 rekanan pengadaan tinta impor. Rusadi menunjuk lebih dari satu rekanan, dan Achmad mengetahui bahwa hal tersebut bertentangan dengan aturan. Keduanya meloloskan 8 rekanan pengadaan tinta impor dengan ketentuan untuk dipergunakannya tinta yang dibuat dan diimpor dari India. Bahkan sampai saat itu, tidak ada penjelasan mengenai Harga Perkiraan Sendiri (HPS), dan rapat hanya dihadiri keduanya tanpa anggota panitia yang lain.

Rapat selanjutnya, Achamad dan Rusadi kemudian membicara mengenai berbagai hal, termasuk negosiasi harga. Oleh karena penawaran harga oleh rekanan masih melebihi anggaran, maka keduanya menetapkan harga sesuai dengan zona atau 4 wilayah pemilihan. Tindakan ini juga bertentangan dengan peraturan.Kemudian dibuat Surat Keputusan rekanan yang juga bertentangan dengan peraturan.

Achmad dan Rusadi membuat HPS dan kelengkapan surat lainnya tanpa ditetapkan oleh Ketua KPU. Keduanya pun berangkat ke India untuk meninjau pabrik tinta di sana dengan fasilitas dan akomodasi dari 4 rekanan tinta impor, padahal telah diterima

\footnotetext{
diakses dari http://www.ptjambi.go.id/uploads/others/perbuatan_melawan_huku m_materiil_dalam_tipikor_pada_praktik_peradilan_i ndonesia.pdf, pada tanggal 29 September 2014.
} 
pula biaya perjalanan dinas dari KPU sebesar Rp 81.000.000,00. Setelah adanya pembayaraan pengadaan tinta dari KPU, salah satu rekanan tinta menyerahkan uang sejumlah Rp 70.000.000,00 kepada Rusadi dan telah ia serahkan juga kepada Kabiro Keuangan KPU.

Akibat perbuatan Rusadi yang bertentangan dengan peraturan ini, Negara dianggap telah mengalami kerugian yang setidaknya mencapai jumlah Rp1,382 miliar.Berdasarkan hasil pemeriksaan, ditemukan beberapa fakta sebagai berikut: ${ }^{33}$

1. bahwa sebelum pengadaan tinta sidik jari diumumkan, ada beberapa perusahaan yang menemui Biro Logistik KPU untuk keperluan pengadaan tinta,

2. bahwa KPPU menemukan adanya beberapa oknum yang tidak memiliki perusahaan, tetapi menggunakan perusahaan orang lain untuk mengikuti tender,

3. bahwa panitia tender telah memberlakukan pengetatan persyaratan tinta yang dimaksudkan untuk meluluskan empat konsorsium yang selanjutnya menjadi pemenang tender yang telah bersepakat untuk memberi uang terima kasih, dan membiayai perjalanan pejabat KPU ke India.

Berdasarkan fakta-fakta yang ada, maka Pengadilan Negeri No. 10/PID.B/TPK/2005/PN.JKT.PST tertanggal

\footnotetext{
33 Rengga Damayanti, "Pemenang Tender Tinta Pemilu 2004 Adalah Pabrik Cat", diakses dari http://nasional.tempo.co/read/news/2006/01/12/0557 2161/pemenang-tender-tinta-pemilu-2004-adalahpabrik-cat, pada tanggal 9 Agustus 2015 pukul 15.00 wib.
}

17 Februari 2006 menyatakan bahwa Rusadi telah memenuhi dakwaan, yaitu Pasal 2 ayat (1) jo Pasal 18 UU No. 31 Th 1999 sebagaimana telah diubah dengan UU No. 20 Th. 2001 jo Pasal 55 ayat (1) ke-1 jo KUHPidana. Oleh karenanya, Rusady dinyatakan bersalah dan dihukum pidana penjara selama 4 (empat) tahun, serta denda Rp 200.000.000,- dan uang pengganti Rp1.382.367.515,.

Pengadilan Tinggi No. 03/PID/TPK/2006/PT.DKI pada tanggal 18 Mei 2006 menjatuhkan pidana penjara 4 (empat) tahun, dan denda Rp 200.000.000,.Mahkamah Agung No. 1974 K/PID/2006 pada 13 Oktober 2006 menjatuhkan pidana penjara 4 (empat) tahun, dan denda $\mathrm{Rp}$ 200.000.000,-. Mahkamah Agung dalam putusannya sependapat dengan jaksa yang mendakwa Rusadi telah melakukan perbuatan korupsi dengan memperkaya orang lain, yang dalam hal ini 4 rekanan perusahaan tinta impor dengan nilai total $\mathrm{Rp}$. 4.326.000.000,00 dan 3 rekanan perusahaan tinta total dengan nilai total $\mathrm{Rp}$. 335.100.000,00, sehingga total kerugian mencapai Rp 4.661.100.000,00. ${ }^{34}$

Pada putusan pengadaan tender tinta pemilu, meskipun unsur negara tidak dirugikan, dan pelaksanaan pemilu berjalan baik (kepentingan umum terlayani), tetapi terdakwa dinyatakan mendapat untung, yaitu berupa fee atau uang terima kasih, dan fasilitas perjalanan ke India. Oleh sebab itu, terdakwa tetap dijatuhi pidana selama 4 (empat) tahun penjara. Putusan Mahkamah

34 Widiada, "Kebijakan Legislasi tentang Sifat Melawan Hukum Materiil Dalam Tindak Pidana Korupsi", Disertasi Program Ilmu Hukum, Bandung:, Universitas Katolik Parahyangan, 2008, hlm. 361-362. 
Konstitusi 2006 yang mengakibatkan kekosongan norma hukum terhadap pengaturan perbuatan melawan hukum materiil dalam tindak pidana korupsi pada kebijakan legislasi, terlihat pada kasus ini tidak berpengaruh pada Putusan Mahkamah Agung yang tetap memberlakukan sifat melawan hukum materiil sebagai kaidah hukum dalam memutuskan perkara.

Pertentangan atau perbedaan antara Putusan Mahkamah Agung dan Mahkamah Konstitusi ini menunjukkan adannya ketidakserasian dalam menafsirkan unsur melawan hukum materiil, sehingga para penegak hukum, khususnya hakim yang memegang tongak keadilan dalam memutuskan perkara pada kasus konkrit. Meskipun tidak ada ketentuan dalam undangundang tindak pidana korupsi yang mengatur mengenai sifat melawan hukum materiil, hakim dapat mengikuti yurisprudensi yang ada, dan berdasarkan pada doktrin atau ajaran hukum pidana, dapat melakukan penafsiran terhadap unsur melawan hukum yang tidak hanya dalam pengertian formal, tetapi juga dalam arti materiil dengan memerhatikan hukum (tidak tertulis) yang hidup dalam masyarakat. Dengan penafsiran tersebut, pertimbangan dan hasil putusan hakim yang memberlakukan sifat melawan hukum materiil negatif dapat mencapai tujuan hukum karena memenuhi rasa keadilan, dan memberikan kemanfaatan, tanpa mengesampingkan asas kepastian.

\section{KESIMPULAN}

Doktrin hukum mengenal adanya ajaran sifat melawan hukum materiil berfungsi negatif yang bersumber dari hukum tidak tertulis yang digunakan sebagai dasar pembenar yang menghapuskan sifat melawan hukum dari suatu perbuatan, sehingga pelaku menjadi tidak dapat dipidana, meskipun perbuatan tersebut bertentangan dengan hukum secara formal. Penggunaan hukum tidak tertulis merupakan hal yang tidak dapat dihindarkan karena hukum selalu berkembang dan hidup dalam masyarakat, sehingga pada kejadian tertentu adakalanya hukum tertulis tidak dapat memenuhi tuntutan kebutuhan hukum yang ada dalam masyarakat. Hal ini semakin memperkuat akan adanya keyakinan masyarakat terhadap nilai-nilai hukum yang bersumber di luar ketentuan Undang-Undang. Adapun nilai hukum yang berdasarkan kriterianya menjadi tolak ukur yang dapat digunakan sebagai dasar dari sifat melawan hukum materiil negatif, yaitu Negara tidak dirugikan, kepentingan umum dilayani, dan terdakwa sendiri tidak mendapat untung. Apabila suatu perbuatan memenuhi satu saja dari ketiga hal di atas, maka penegak hukum, khususnya hakim wajib melakukan pertimbangan, bahkan hingga melakukan pembenaran terhadap tindak pidana tersebut, terutama bila dalam satu perbuatan didapati tiga alasan pembenar ini di dalamnya. Meskipun terdapat keputusan Mahkamah Konstitusi yang menyatakan bahwa sifat melawan hukum materiil tidak mengikat, tetapi pasca putusan MK tersebut, Mahkamah Agung dalam putusannya memperlihatkan bahwa ketiga tolak ukur dari hukum tidak tertulis yang digunakan tetap relevan untuk diberlakukan dalam kasus tindak pidana korupsi. 


\section{DAFTAR PUSTAKA}

\section{Buku-buku dan Artikel Ilmiah:}

Abdulkadir Muhammad, Hukum Perdata Indonesia, Bandung: Citra Aditya Bakti, 2000.

Arya Maheka, Mengenali \& Memberantas Korupsi, Komisi Pemberantasan Korupsi, Jakarta: Komisi Pemberantasan Korupsi, tidak bertahun.

Barda Nawawi Arief, Pembaharuan Hukum Pidana Dalam Perspektif Kajian Perbandingan, Bandung: Citra Aditya Bakti, 2011.

Chaerudin, Syaiful Ahmad Dinar, Syarif Fadilah, Strategi Pencegahan dan Penegakan Hukum Tindak Pidana Korupsi, Bandung: Refika Aditama, 2008.

\section{E.Y.Kanter, S.R. Sianturi, Asas-Asas Hukum Pidana di Indonesia dan Penerapannya, Jakarta: Storia Grafika, 2012.}

Erdianto Effendi, Hukum Pidana Indonesia, Suatu Pengantar, Bandung: Refika Aditama, 2011.

Evi Hartanti, Tindak Pidana korupsi, Jakarta: Sinar Grafika, 2014.

Gatot Supramono, Tindak Pidana Korupsi di Bidang Perkreditan, Bandung: Alumni, 1997.
H. Adami Chazawi, Hukum Pembuktian Tindak Pidana Korupsi UU No. 31 Tahun 1999 diubah dengan UU No. 20 Tahun 2001, Bandung: Alumni, 2008.

H. M. Hamdan, Alasan Penghapusan Pidana, Teori dan Studi Kasus, Bandung: Refika Aditama, 2012.

Indriyanto Seno Adji, Tindak Pidana Ekonomi, Bisnis, dan korupsi Perbankan, Modul Kuliah "Kejahatan Bisnis" , Bandung: Universitas Padjajaran Program Pascasarjana, 2004.

Komariah Emong Sapardjaja, Ajaran Sifat Melawan-Hukum Material Dalam Hukum Pidana Indonesia, Jakarta: Mahkamah Agung RI, 2008.

Marwan Mas, Pemberantasan Tindak Pidana Korupsi, Bogor: Ghalia Indonesia, 2014.

R. Achmad S. Soemadi Praja, Pengertian Serta Sifatnya Melawan Hukum bagi Terjadinya Tindak Pidana (Dihubungkan dengan Beberapa Putusan Mahkamah Agung), Bandung: Armico, 1983.

Roeslan Saleh, Perbuatan Pidana dan Pertanggungjawaban Pidana, Dua Pengertian Dasar Dalam Hukum Pidana, Jakarta: Aksara Baru, 1983.

Romli Atmasasmita, Analisis dan Evaluasi Hukum tentang Penyelidikan dan Penyidikan Tindak Pidana Korupsi, 
Jakarta: Badan Penelitian Pembinaan Nasional Departemen Hukum Dan HAM, 2007.

Satochid Kartanegara dan Pendapat2 Para Ahli Hukum Terkemuka, Telah dikupas ke dalam Bahasa Indonesia dari Bahasa Belanda, Hukum Pidana kumpulan kuliah, Balai Lektur Mahasiswa, tanpa penerbit, tanpa tahun.

Schaffmeister, N. Keijzer, E. PH. Sutorius, Terjemahan JE. Sahetapy dan Agustinus Pohan, Hukum Pidana, Bandung: Citra Aditya Bakti, 2011.

Widiada, "Kebijakan Legislasi tentang Sifat Melawan Hukum Materiil Dalam Tindak Pidana Korupsi”, Bandung: Disertasi Program Ilmu Hukum, Universitas Katolik Parahyangan, 2008.

\section{Website:}

http://www.kompasiana.com.

http://www.pt-jambi.go.id.

http://hukum.unsrat.ac.id.

http://nasional.tempo.co. 